Notes and Queries (2016) 63 (3):pp-pp.

doi: $10.1093 /$ notesj/TBA

To be published online: September 2016

\title{
CHRISTOPHER MARLOWE AND GERVASE MARKHAM
}

One of the posthumous tributes frequently quoted by Marlowe's biographers is the reference to 'kynde Kit Marlowe' in manuscript The Newe Metamorphosis (1600) by 'J.M, Gent'. J.M. writes of Marlowe finishing Hero and Leander 'if death not prevent him' on the grounds that 'love such art hath lent him'. Although J.M. is still frequently taken to be John Marston, it is nearly a hundred years since John Henry Hobart Lyon demonstrated conclusively that the author could not be Marston and, equally conclusively, identified him as Gervase Markham, who used the $\mathrm{J}$ and $\mathrm{G}$ forms of his name interchangeably. John Marston must be ruled out because the known facts of his life conflict with those the author of The Nerve Metamorphosis reveals about himself. In Lyon's words:

'His name was not "Frenche"; he probably was never a soldier; there is no record of his being present at the taking of Cadiz, or in Ireland and Flanders; he attacked the Puritans and showed no attachment for Essex; he had no interest in the life and occupations of the country; he was not fond of digressing into homely practical details; he was not a Cambridge man and made no parade of his learning; he did not live on the "outer" border of East Anglia; his handwriting differed from that of The Newe Metamorphosis; and his style was markedly unlike that of J.M.'

What is not true of Marston, however, is true of Markham, and Lyon's monograph established his authorship of The Newe Metamorphosis beyond reasonable doubt.

In both Markham's accepted works and in The Newe Metamorphosis, there is a 'scarcity of reference to writers of the time'. ${ }^{2}$ The reference to 'kynde Kit Marlowe', in other words, stands in stark contrast to Markham's usual practice. That Markham describes Marlowe as 'kind' in a text dated 1600, particularly given the less-than-flattering public reputation that Marlowe had developed

\footnotetext{
${ }^{1}$ John Henry Hobart Lyon, A Study of the Newe Metamorphosis (1919), 121.

2 Ibid., 154.
} 
posthumously as a result of the uninformed religious propaganda in texts such as Thomas Beard's In The Theatre of God's Judgements (1598), suggests the possibility that the author knew Marlowe personally, and was offering an alternative view. Consider the variety of single-syllable adjectives that might have been substituted for 'kind' and this possibility becomes even stronger. Some writerly epithets, such as 'sweet Shakespeare', can clearly be connected to the author's writing style (as Ernst Honigmann and Katherine Duncan-Jones have argued); 'sweet' being appropriate to a writer described as 'honey-tongued' and the author of 'sugar'd sonnets'. 'Kind', however, is not a fitting adjective for Marlowe's poetic or dramatic style. Therefore, it more likely reflects Markham's personal experience of the author. Whatever damage has been done to Marlowe's posthumous reputation by his apparently violent death, Markham's assessment of him as 'kind' is certainly in line with the tributes of those we can confirm as his friends: Thomas Nashe, who numbered Marlowe among 'my friends that used me like a friend', and Edward Blount, who - addressing Thomas Walsingham - called Marlowe 'the man that hath been dear unto us'.

Until now, Markham and Marlowe have been linked only by twenty-four lines beginning 'I walkt along a streame' from Markham's Devoreux (1597), attributed to Marlowe in England's Parnassus (1600) and accepted as his for 350 years. A possible friendship between Markham and Marlowe has not previously been explored, but Gervase Markham and Christopher Marlowe would have found many points in common. The only surviving letter by Gervase confesses a love of poetry: 'For my loue to poesye if it be an error I confes my selfe faultye' ${ }^{3}$ In the early 1590 s, Markham was 'a gay narrator of salacious Ovidian tales', ${ }^{4}$ a description that would fit Marlowe equally neatly. In 1593, when Marlowe is thought to have been working on Hero and Leander, Gervase Markham registered a work (now lost) called Thyrsis and Daphne, believed to be, like Marlowe's text, an amatory poem similar in treatment to Venus and Adonis. ${ }^{5}$ It is likely that both were present at Cambridge University at the same time. Marlowe was at Corpus Christi from

\footnotetext{
${ }^{3}$ Frederick Poynter, A Bibliography of Gervase Markham, 1568?-1637, (1962), 18.

${ }^{4}$ Lyon, 156.

${ }^{5}$ Ibid., 128.
} 
December 1580 to the summer of 1587 , whereas the younger Gervase is thought to have been 'one of the two students simply called Markham who entered King's College, Cambridge, at Easter 1583', following his brother Francis, who was certainly educated there. ${ }^{6}$

Markham's family were well connected and 'had a tradition of service to the Crown dating back to the 12th century'. Gervase's great-grandfather, Sir John Markham, was knighted by Henry VIII and married Anne Neville, a cousin of Henry VII. But on Sir John's death the larger part of his inheritance was bequeathed to his sons from a later marriage, and the Cotham branch of the Markham family found themselves in reduced circumstances. ${ }^{7}$ Gervase's older brother Francis was a page in the household of the Earl of Pembroke, and later joined the household of the Earl of Shrewsbury. ${ }^{8}$ It is probable that Gervase was brought up in the household of the Earl of Rutland, whose country seat Belvoir Castle was four miles from his father Robert Markham's house in Cotham. A letter from Sir Francis Walsingham to the Earl of Rutland in 1584 refers to his 'servant Iarvys Markham'. ${ }^{9}$

According to Gerard Langbaine, Markham was 'esteem'd a good Scholar, and an excellent Linguist, understanding perfectly the French, Italian and Spanish Languages' ${ }^{10} \mathrm{He}$ shared these qualities with Marlowe, who translated Ovid's Amores and Lucan's First Book out of Latin and used French sources for Tamburlaine and The Massacre at Paris; $;^{11}$ the connections between his Dido Queen of Carthage and Ludovico Dolce's Didone (1547) suggest he could also read

\footnotetext{
6 Matthew Steggle, 'Markham, Gervase (1568?-1637)',Oxford Dictionary of National Biography, Oxford University Press, 2004; online edn, Oct 2006 [http://www.oxforddnb.com/view/article/18065, accessed 4 June 2015]

7 Poynter, 5.

${ }^{8}$ D. J. B. Trim, 'Markham, Francis (1565-1627)',Oxford Dictionary of National Biography, Oxford University Press, 2004 [http://www.oxforddnb.com/view/article/18063, accessed 30 Jan 2016]

9 Poynter, 5, 8.

10 Gerard Langbaine, An account of the English dramatick poets, 1691, Oxford, 340.

11 Ethel Seaton, 'Fresh Sources for Marlowe', Review of English Studies 5:20 (1929) 385-401 and Julia Briggs,

'Marlowe’s Massacre At Paris: A Reconsideration', Review of English Studies, 34:135 (1983) 257-278.
} 
Italian. ${ }^{12}$ Marlowe's recently established interest in horses ${ }^{13}$ would have given the two men another point in common. Gervase Markham was 'the favourite authority during his lifetime on the horse and horsemanship', writing a considerable number of books on the subject. ${ }^{14}$

Marlowe and Markham's mutual indebtedness to the Walsingham family provides a mechanism for their personal acquaintance. Gervase Markham dedicated his Poem of Poems or Sion's Muse (1596) to Elizabeth, daughter of Sir Philip Sidney and Frances Walsingham; it was signed (as with The Nerwe Metamorphosis), 'I.M'. Frances was the daughter of Sir Francis Walsingham, and second cousin to Thomas Walsingham, Marlowe's patron, whose home at Scadbury in Kent is recorded in Privy Council records as the most likely place Marlowe would be found in May 1593. Thomas Walsingham had been taken under his older cousin's wing as early as 1581, when both he and Marlowe's friend Thomas Watson accompanied Sir Francis to the Paris Embassy. Subsequently the younger Walsingham continued to work for his cousin on intelligence matters, from an office in Sir Francis's house in Seething Lane. Marlowe's personal connection to Sir Francis is confirmed by Thomas Watson, who mentioned Marlowe (as 'Faustus') in his 1590 elegy on the older man's death. ${ }^{15}$ Marlowe's work as an intelligence agent for Sir Francis Walsingham is now widely accepted on the evidence of the Privy Council note of 1587 which records he had 'done her Majestie good service... emploied as he had been in matters touching the benefitt of his Countrie'.

If Marlowe was indebted to Sir Francis Walsingham for part of his income, then so was Markham, whose success as a horse expert could be traced directly to him. Gervase Markham's father, Robert Markham, was 'a close friend of Sir Francis Walsingham, who had presented Gervase's father with an expensive Arabian horse as a gift. Gervase as a young man was given the

\footnotetext{
12 Mary E Smith, 'Marlowe and Italian Dido Drama', Italica 53:2 (1976), 223-235.

${ }^{13}$ David Mateer, 'New Sightings of Christopher Marlowe in London', Early Theatre, 11:2, (2008),13-38.

${ }^{14}$ Lyon, 126.

15 Nicholl, Charles (1992). The Reckoning: the murder of Christopher Marlowe. London: Jonathan Cape. p. 115.
} 
task of training it. ${ }^{16}$ His service in the Rutland household would have enhanced his equestrian expertise, for the earl kept 'a great many horses...[and] was in the habit of lending mounts to his friends for the hunt.' ${ }^{17}$ Gervase would later rely on his horse-related publications for his livelihood. In his dedication to The Poem of Poems or Sion's Muse (1596), Markham describes Sir Francis as one 'to whom my Name was ever immortallie obliged'. If Marlowe and Markham's common interests did not bring them together at Cambridge, they are likely to have come to know each other through this mutual connection with the Walsinghams.

A personal acquaintance between Marlowe and Gervase Marlowe would unravel the mystery of the posthumous dedication of Thomas Watson's Amintae Guardia to Mary Sidney, Countess of Pembroke, by one 'C.M'. Marlowe's documented friendship with Thomas Watson has caused numerous scholars to attribute this dedication to him, despite there being, as Tucker Brooke wrote, 'small reason to suppose that Marlowe ever belonged to the Countess of Pembroke's circle'. ${ }^{18}$ A friendship with Gervase Markham, however, could offer Marlowe such a connection. Gervase's brother Francis Markham wrote an autobiography in which he revealed that he was 'First brought up at my lord of Pembroke's, whose wife was Catherine daughter of ye earl of Shrewsbury'. ${ }^{19}$ This was Henry Herbert, the second Earl of Pembroke, whose second wife was Mary Sidney, the dedicatee of Amintae Guardia. In the early 1590s, the earl would become patron of Pembroke's men, whose plays in 1592-3 included Marlowe's Edward II. As a result of his brother's being 'brought up' at the Pembroke home, Gervase Markham is likely to have been on relatively familiar terms with the Earl and Countess. If Marlowe were personally acquainted with Gervase Markham, as the latter's unusual personal tribute 'kynde Kit Marlowe' suggests, it would be little wonder if Marlowe attempted to make use of this connection.

\footnotetext{
16 Joan Thirsk, The Rural Economy of England, p.392

${ }^{17}$ Poynter, 9.

18 Tucker Brooke, "The Marlowe Canon," PMLA 37, no. 3 (1922): 414.

${ }^{19}$ Lyon, 125.
} 
ROSALIND BARBER

Goldsmiths, University of London. 